\title{
Fair Debts Management for Sustainable Development
}

\author{
Most. Asikha Aktar* \\ Department of Economics, Comilla University \\ Cumilla, Bangladesh. \\ Email: asikharita@gmail.com \\ Mu'ath Hesham Metlaq Al-Azzam \\ School of Tourism, Hospitality and Event management \\ Universiti Utara Malaysia \\ Sintok, Kedah, Malaysia \\ Email:moadalazzam@yahoo.com \\ Md. Mahmudul Alam \\ School of Economics, Finance and Banking \\ Universiti Utara Malaysia, Sintok, Kedah, Malaysia \\ Email: rony000@gmail.com \\ *Corresponding Author
}

\section{Citation Reference:}

Ali, M.K., Aktar M.A., \& Alam M.M. (2021). Fair Debt management for Sustainable Development. In: Walter Leal Filho et al. (eds), Reduced Inequalities: Encyclopedia of the UN Sustainable Development Goals. Springer, Cham. ISBN: 978-3-319-71060-0. (online) https://doi.org/10.1007/978-3-319-71060-0_68-1

This is a pre-publication copy.

The published article is copyrighted by the publisher. 


\section{Fair Debts Management for Sustainable Development}

\section{Definition}

Debt is created when having to pay back a loan is greater than the opportunities to make a profit or some form of financial security, and this is no different when a state's socio-economic growth depends on the resources required (Nicu 2011). Resources from foreign markets can be either consumed to raise the standard of living (in the short term) or invested in enterprises that increase business opportunities, employment, infrastructure, and development of technological and human capital. Simply put, 'debt sustainability' is the ability of a government being able to satisfy its current and future debt obligations or paying back arrears (Abdulkadri 2014). The issue of 'debt sustainability' has highlighted the importance of 'fair debts management' practices and this type of management is defined as government responding fairly to debts that have to be paid (Dottori and Manna 2016). In a broader macroeconomic context, 'fair debts management' safeguards the financing needs of a government in terms of reducing long-term costs and restraining the risks involved (IMF and WB 2003). It contributes to sustainable development by ensuring that people who are in danger of financial distress are adequately assisted during the recovery process.

\section{Introduction}

As a concept based on the Brundtland Report published in 1987, sustainable development refers to "development that meets the necessities of the present without undermining the capacity of future generations to meet their necessities" (General Assembly of the United Nations 1987). The long-term protection of the environment and the economy is the core of sustainable development (SD), which can only be accomplished by resolving economic, environmental, and social issues in the process of policymaking (Dernbach 2003; Stoddart 2011). One of the key issues in the implementation of sustainable development is the fair management of a country's financial capital (Ari and Koc 2018). Access to financial capital for sustainable development depends on a number of factors, among them the debt portfolio of a government which documents the sources of financial capital lent to a country (Ayadi and Ayadi 2008). The 2015 Addis Ababa Action Agenda (AAAA) called on a wide range of parties to mobilise domestic and external debt so that they are more equally redistributed, for instance central and local governments, private investors and philanthropists. The end game should be economic growth that improves human well-being and protects the environment.

In general, debt is defined as the amount due in currency, at some point, by one country(s) to another country(s)and/or by an international financial institution, based on the credits obtained by the State(s), by private undertakings guaranteed by the State, and also by undertakings or individuals which remain payable for more than one year (Iulian 2000). It involves risky and complex financial structures and can create significant risks to the government's balance sheet and the country's financial sustainability. In this context, there is a need to connect the 'fair debts management' concept to a consistent macroeconomic framework in which governments aim to ensure that the growth rate of debt does not compromise either investments in long-term structural transformation or attaining sustainable development goals (SDGs).

The present study examines the importance of 'fair debts management' for sustainable development. It begins by discussing what "debt" means and its structure, then explains debt 
for sustainable development. Explained here are the important features of "fair debts management" and the final section concludes this paper with a summary of the main themes covered here.

\section{The Meaning of "debt"}

In economics, the notion of debt is the key and this term applies to people's or organizations' financial transactions. The act of borrowing is what creates a debt. Oyejide et al. (1985) defined debt as use of resources or money by an institution that its owner does not contribute to and does not belong to them in any other way. In contemporary law, there does not exist any exact fixed meaning of debt but it may generally be viewed as that which is legally held by one person to another or an agreement to make payment or restitution of money enforceable by legal action.

The debt is a public debt when it is borrowed by a government (Adepoju et al. 2007). Public debts encompassing internal and external types are government debts accumulated by borrowing to fund domestic investment in national and international markets. An internal public debt facilitates the identification of loans from the domestic economy, either directly or enforced by the state, by persons and legal entities resident, in local or foreign currency, by local authorities or governments, for various periods. External public debt enables a country to absorb and spend beyond its domestic output potential, so capital growth is not only funded by the mobilization of domestic savings, but also by the extraction of money from countries with capital surpluses. The role of debt is therefore to reduce a manager's freedom of choice in business decisions and ensure that repayments are factored in when making investment decisions (Myers 1977; Jensen 1986). D'Mello and Miranda (2010) have stated that overinvestment is diminished by debt.

Debts are generally divided into two main types, i.e. reproductive debts and dead weight debts. When a loan is received to allow the state or country to purchase some kinds of properties, the debt is reproductive, e.g. money lent for the purchase of power utilities, refineries, factories, etc. However, dead weight debts are related to those that are undertaken to fund battles and spend on existing liabilities. When a country acquires a loan from abroad, it means that the government can borrow goods and services from abroad at the value of the loan without having to sell anything for exchange at the same time. The same country would have to bear the responsibility of exporting goods and services without obtaining any imports in return if capital and interest are to be repaid. The form of burden exchange for goods and services does not apply to internal loans. Nevertheless, these two forms of debt demand that the interest and principal cost (debt service) be paid by the borrowers' future savings. Therefore, investment funded by debt needs to be efficient and very well managed to achieve a rate of return higher than the debt servicing expense.

Moreover, debt will be effective for sustainable development if it is able to be serviced without undermining a society's social and economic growth (Abdulkadri 2014). 'Fair debt management' as a way of preserving debt for sustainability, according to Kregel (2006), from the Millennium Development Goals to the 2030 Agenda, is a collection of policies that will allow a nation to attain SDGs by 2030 without growing inequality. It gives priority to the funding conditions of the 2030 Agenda and establishes that debt must be seen as a support mechanism for the poorest countries that rely on global financial institutions. It also highlights SD-goal 10 targets which is one of the most striking and groundbreaking elements of the 2030 
Agenda, making it possible for many countries to overcome their financial problems and tackle domestic inequalities at the same time.

\section{The General Structure of Debt}

In normal situations, many companies and individuals take on public debt to get finance what they want to achieve, which are usually very expensive in the first place. With this example as a starting point, it is clear that public debt records are maintained on a loan-by-loan basis. These documents are aggregated according to different parameters, often short-term and long-term in character, form of flow, nature of the lender or creditor, in order to prepare statistics (see Box $1)$.

\section{Box 1: The general structure of public-debt related flows}

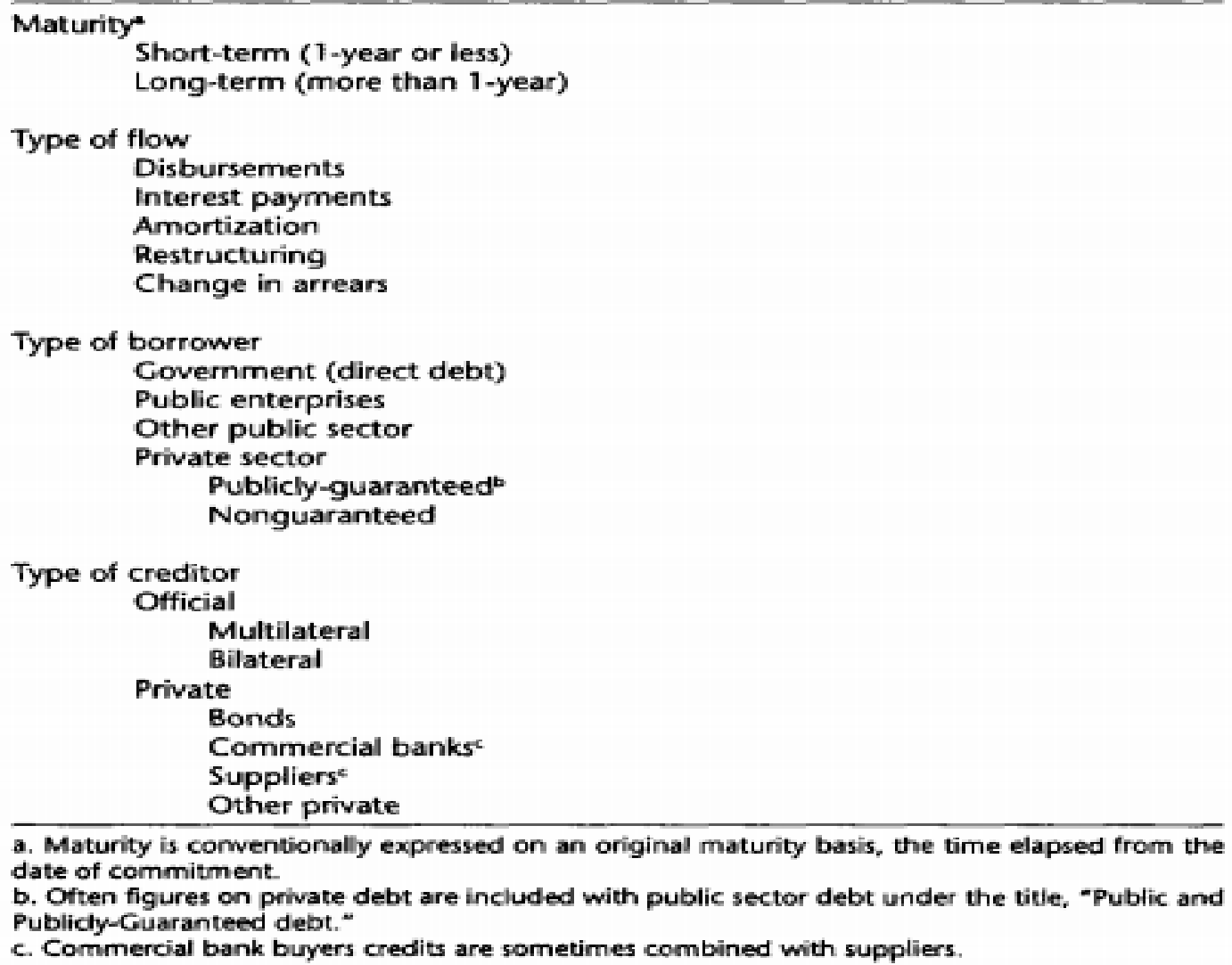

a. Maturity is conventionally expressed on an original maturity basis, the time elapsed from the date of commitment

b. Often figures on private debt are included with public sector debt under the titie, "Public and Publicly-Guaranteed debt."

c. Commercial bank buyers credits are sometimes combined with suppliers.

Source: Adapted from Klein (1994)

Data that refers to both types of debts i.e., long-term public debt and publicly guaranteed debt, is usually available on a loan-by-loan basis to a statistician; it can be structured according to any number of parameters. Only on a highly aggregated basis can short-term debt be obtained, and so the classification possibilities are minimal. The type of flow is another essential classification scheme: the statistics on credit expenditures, payments of debt service, debt restructuring, and arrears accumulation must all be shown separately. The type of borrower and creditor are two potential approaches of grouping debt data. Among creditors, the central 
government's direct debt should be seen separately. It is helpful to identify separately the debt guaranteed by the State that originates from the private sector, since such debts are, in essence, contingent financial liabilities. However, the type of creditors can be broken down into official and private sector creditors. Multilateral or bilateral creditors may, in turn, be official creditors. Suppliers, commercial banks, bond holders, and others are usually grouped under private creditors. Export credits constitute a cross-creditor scheme that is used frequently. Private export credits consist of providers' credits (credits extended to fund their goods by suppliers or contractors) and buyers' credits (i.e. credits from commercial banks to fund their customers' export orders). Official export credits consist of loans from specialist institutions like the U.S. Export-Import Bank to fund purchases of goods by individuals. This can be seen as one group of official credit or combined with private export credit to provide a better form of financing.

\section{Debt for Sustainable Development}

The United Nations National Assembly unveiled a new agenda in September 2015, dubbed 'a plan of action for citizens, the earth and prosperity'. The agenda known as 'Transforming our world: the 2030 Sustainable Development Initiative' is important because it is attempting to deal with the incorporation of strategies to end inequality in today's global economy and how it is developing. Unlike the Millennium Development Goals (MDGs), ending inequality has been incorporated systematically into the SDGs (Freistein and Mahlert 2016) and many other aspects or dimensions are referred to (Table 1). The inclusion of a standalone goal on inequality in the 2030 agenda for sustainable development - goal 10 which promises to reduce inequalities both within and between countries - has the potential to trigger much needed action to narrow the huge divide between 'the haves' and 'the have-nots'. Widely regarded studies have pointed to persisting and emerging inequalities between and within countries; they are believed to be the greatest barrier to sustainable development, and reducing them is imperative for sustainable development according to the agenda (Saiz and Donald 2017).

Table 1: Sustainable Development-Goal 10 (Reduce inequality within and among countries)

10.1 By 2030, progressively achieve and sustain income growth of the bottom 40 per cent of the population at a rate higher than the national average.

10.2 By 2030, empower and promote the social, economic and political inclusion of all, irrespective of age, sex, disability, race, ethnicity, origin, religion or economic or other status.

10.3 Ensure equal opportunity and reduce inequalities of outcome, including by eliminating discriminatory laws, policies
10.1.1 Growth rates of household expenditure or income per capita among the bottom 40 per cent of the population and the total population.

10.2.1 Proportion of people living below 50 per cent of median income, by age, sex and persons with disabilities.

10.3.1 Proportion of the population reporting having personally felt discriminated against or harassed within the previous 12 months on 
and practices and promoting appropriate legislation, policies and action in this regard.

10.4 Adopt policies, especially fiscal, wage and social protection policies, and progressively achieve greater equality

10.5 Improve the regulation and monitoring of global financial markets and institutions and strengthen the implementation of such regulations

10.6 Ensure enhanced representation and voice for developing countries in decisionmaking in global international economic and financial institutions in order to deliver more effective, credible, accountable and legitimate institutions.

10.7 Facilitate orderly, safe, regular and responsible migration and mobility of people, including through the implementation of planned and wellmanaged migration policies.

10.a Implement the principle of special and differential treatment for developing countries, in particular least developed countries, in accordance with World Trade Organization agreements.

10.b Encourage official development assistance and financial flows, including foreign direct investment, to states where the need is greatest, in particular least developed countries, African countries, small island developing states and landlocked developing countries, in accordance with their national plans and programs. the basis of a grounds of discrimination prohibited under international human rights law.

10.4.1 Labor share of GDP, comprising wages and social protection transfers.

\subsubsection{Financial Soundness Indicators.}

10.6.1 Proportion of members and voting rights of developing countries in international organizations.

10.7.1 Recruitment cost borne by employee as a proportion of yearly income earned in country of destination.

10.7.2 Number of countries that have implemented well-managed migration policies.

10. a.1 Proportion of tariff lines applied to imports from least developed countries and developing countries with zero-tariff.

10.b.1 Total resource flows for development, by recipient and donor countries and type of flow (e.g. official development assistance, foreign direct investment and other flows). 
10.c By 2030, reduce to less than 3 per cent the transaction costs of migrant remittances and eliminate remittance corridors with costs higher than 5 per cent. 10.c.1 Remittance costs as a proportion of the amount remitted.

\section{Source: Saiz and Donald (2017)}

Yet the entire effort to create and achieve SDGs was based on the premise that with greater equality the global economy would be gradually 'moving forward'. In this context developing countries are projected to improve their economic growth by an average of 5\% for the period 2015-2030 (UN 2013), with a target of 7\% per annum for the least developed countries. A powerful driver of this transformation would be tackling illicit financial flows, and encouraging financial flows to those states facing financial difficulties which compromise their ability to resolve inequalities (Cecchetti et al. 2011; Antoniades and Griffith-Jones 2018). The Intergovernmental Committee of Experts on Sustainable Development Financing (ICESDF) concludes that 'it is clear that current financing and investment patterns will not deliver sustainable development'. According to the OECD report in 2018, the projected funding amounts necessary to attain the SDGs are in the order of trillions of dollars compared to the billions needed to realise the MDGs. Given the global savings-investment context, they argue for additional financing be given to developing countries, preferably intermediated through official development agencies, for building their fiscal buffers (IMF 2011). If larger flows of equity and debt could be mobilized for developing countries, it would enable them to expand investment in sustainable development, and ensure inequality is at only modest levels in all aspects.

Since 2015, neither developing nor the least developed countries have reached the anticipated growth rates in any single year despite high debt transition. Especially, developing countries have lagged significantly behind, with average growth for 2015-2018 at 4.2\% (WB 2019). Furthermore, over the last decade, global debt has risen in all sectors throughout the world (Antoniades and Griffith-Jones 2018). These dynamics are especially pertinent to the developing countries which are the priority target of SDGs. In 2016 the volume of world debt reached a record high of US $\$ 164$ billion which is equivalent to $225 \%$ of global GDP (IMF 2018).

This is of particular concern because the systemic change implied by the Global Green New Deal and expressed in the Sustainable Development Goals (SDGs) in developing countries would require an unprecedented scaling-up of the financing of productive investment in these countries. Conservative estimates range from at least US\$2 trillion to US\$3 trillion per year to reach only the most basic SDGs (UNCTAD 2019). Meanwhile the bulk of funding (75\%) for sustainable development in developing countries originates from debt-based funding sources, either from external or domestic creditors (Weber et al. 2016). The fact is that many do not have a steadfast public revenue stream (Fischer and Easterly 1990), and many external and domestic creditors are always inclined to pursue collateral through other means (Mitchener and Weidenmier 2010; Bulow and Rogoff 1988).

For instance, in order to complement the scarcity of domestic capital, nations have always relied on external sources of funding because most developing countries have only low levels of savings, which will be called upon to boost economic growth (Mustapha-Abdullahi 2016). 
Decades ago, it was postulated by Krugman (1988) and Sachs (1989) that large stocks of external debt contribute to a debt overhang, resulting in less growth through degraded investment. As well it restricts the ability of suppliers and receivers of developing nations to attain sustainability by abridging their financial flexibility and reducing their capacity to tackle inequality. Lenders' willingness to lend is also further restricted, resulting in severe damage to economic development and society's general well-being because of significant reductions in public investment. Put another way, an increased level of public debt reduces financial and economic well-being of many developing countries which is called the key driving element for sustainable development. This makes the achievement of sustainable development especially difficult because critical government functions are reduced, ultimately impacting on society and creating social unrest (Cecchetti et al. 2011).

Antoniades et al. (2020) report that an increase in debt is not inherently a negative development. However, the severity of debt distress issues currently faced by developing countries, subsequently threaten the successful implementation of SD-Goal 10. Debt repayments rose by 60 percent during 2014-2017 across 126 developing countries and are now at the highest level since 2004. (Jubilee Debt Campaign 2018). This means that a rising percentage of developing countries' income is not directed towards investments that help them achieve SD-Goal 10, but towards servicing their debt instead. The extent of this burden can hardly be overstated in certain instances. According to UNCTAD (2018) even interest payments, as a percentage of government income, more than doubled from 5.7\% in 2008 to 14\% in 2017 for the poorer economies. Meanwhile, the unstable and worsening state of the global economy exacerbates these adverse dynamics. In recent annual reports, the IMF (2019) refers to a 'weakening global expansion' and the World Bank (2019) to 'darkening skies'. Both institutions refer to the fact that debt can help attain sustainable development only if it is fairly managed in an environment with sound macroeconomic policies. It is an important prerequisite for reducing economic inequality while at the same time consolidating economic development (Ajao and Ogiemudia 2013).

\section{Fair Debts Management for Sustainable Development}

Sustainable development is a concept integrating three aspects - economic, social and environmental. In Brundtland Report (1987), sustainable development was defined as "development that meets the needs of the present without compromising the ability of future generations to meet their own needs" (WCED, 1987). This concept advances the topic of sustainable development beyond the conventional development emphasis on steady, environmentally sustainable economic progress including social development. The premise is that economic development will create a wealthier world that is environmentally stable. In general, it is a key approach to achieving desired social, economic, and environmental outcomes involving all sectors of the economy from transportation, energy development, infrastructure, agriculture, water availability and urbanization simultaneously (Dincer and Rosen 2005).

The Panel of Eminent Persons asked in preparing the SDGs that "targets can only be deemed 'attained' if they are reached for all related income and social classes" (Freistein and Mahlert 2016). Although this proposal has not been included in the final declaration, the Statistical Commission's current indicator proposal at least proposes that the "Sustainable Development Target Indicators should be broken down by income, sex, age, race, ethnicity, migratory status, disability and geographic location, or other characteristics, where applicable". Nevertheless, in their vocabulary, the probably more fundamental characteristic of the SDGs with regard to 
inclusion issues and relative inequality is to be found, namely, that they are conceived as common development goals for all countries (and individuals) alike.

Meeting future generations' needs depends on how social, economic and environmental objectives can be balanced with the demands of achieving equality. Given the times in which we now live, everybody now is required to think more creatively, cohesively and collaboratively because we are now facing extreme economic inequality throughout the world. It is one of the most urgent issues of our time, exacerbating poverty and hindering development (economic), undermining the full spectrum of human rights (social) and damaging terrestrial ecosystems (environmental).

Fair management of public debt by a country's government plays a prominent role in addressing the profound challenges of sustainable development of this century, such as alleviation of poverty, sustainable use of natural resources, and mitigation of the dangers posed by climate change. Societies and investors (i.e. organizations and/or individuals) profit from receiving debt, along with their governments, because they have a shared interest in well-governed and well-functioning economic, social and environmental structures. Societies benefit from enhancing the quality of life, reducing social disparities and driving economic growth when domestic resources and effective use of funding are mobilized (Calderón and Servén 2004). Person and/or institutional investors benefit from investments in public infrastructure, which traditionally has inherent low debt default rates, offering a reliable long-term return (Default Research 2017).

Subsequently, concerning the occurrence of extraordinary events arising from increasing debt levels as stated previously, governments around the world are now cautioned to avoid debt levels beyond certain thresholds, such as the Maastricht criteria adopted by the EU (1992), and are focusing on fair management of debt in order to tackle inequality (Fischer and Easterly 1990). In the context of the United Nations Millennium Development Goals, such a strategy of 'fair management of public debt' that focuses on SD-Goal 10 as an integral part of long-term national development plans was introduced. It has garnered renewed interest with the emergence of the much more ambitious 2030 sustainable development agenda (Kregel 2006; Pinto 2018). Also, the issues of 'fair management of public debt' has become much more prominent at both at national and international levels due to the lack of policymakers concentrating on: firstly, the advantages of a prudent debt management policy to ensure sustainable development; and secondly, the costs of a poor macroeconomic management of unsustainable levels of public debt. Moreover, 'fair debts management' is now a priority concern for any government (Harris and Lane 2018), given that debt levels can be low but could also lead to accumulation and sustainability problems if not managed well. Fair management of debt, alongside right contingent liability management strategies, will make countries less vulnerable to contagion and financial risk by ensuring that the government's own portfolio management does not become a complex problem for private sector financial institutions that lend money.

The "public debt" is the cumulative amount of money held by a government owed to creditors, and this debt is generally accepted (Teică 2012). Fair management of public debt allows individuals to balance their revenue and expenditure (consumptions) under fluctuating economic conditions. It also allows companies, when their sales and business deals are fluctuating at severe and unforeseen levels and times, to offset their investment and production requirements. It also permits governments to better manage the fluctuations in revenues and 
uncertainties from taxes, expenditures, and incomes. There is growing agreement on the concept of 'fair debts management' because it is envisaged as being able to reduce the vulnerability of medium- to long-term contagion and financial shocks, and make the sustainable development goals (SDGs) achievable.

Most importantly, this includes organizing financial transactions so that they are as equitable as possible, including a set of policies that will allow a country to attain SD-Goal 10 without increasing the debt ratios:

$>\quad$ Debt managers, central bankers and fiscal policy advisors, given the interdependencies between their various policy instruments, should share an understanding of well understand the priorities of debt management, fiscal and monetary policies.

Debt management objectives should be well-defined and publicly revealed, as well as the risk and cost measures to be implemented are clarified.

$>\quad$ The debt management organizational structure should be clearly defined to ensure that obligations and responsibilities are well articulated.

The risks inherent in the public debt system should be closely controlled and assessed. To the extent possible, these risks can be mitigated by adjusting the debt structure, considering the cost(s) of doing so.

$>\quad$ A system should be developed to allow debt managers to define and manage the trade offs in the debt portfolio between anticipated risk and cost.

$>\quad$ Debt managers should warrant that their strategies and activities are compatible with the creation of an efficient government securities market in order to reduce risk and cost over the medium- to long-term.

$>\quad$ In order to achieve a long-term solution to the external debt crisis, the nation's export trade must be actively promoted and managed, and imports must be reduced significantly.

The period of implementation must be sufficiently long (10 years or more) before dividends can be repatriated in order for the investment to mature. An effective approach is to ensure the fair operation of financial transactions in order to raise the average tenure of the debt and facilitate such payments over a longer period of time (Giavazzi and Pagano 1990; Calvo and Guidotti 1990; Missale et al. 2002). The conclusion was that this process reduces the risk of repayment and thus raises the expectation of successful fiscal policy.

$>\quad$ With careful management, the government can ensure that debt relief does not compromise educational and healthcare facilities, and money is available to spend on improving the lives of millions of people.

External financing should only be used for top-priority projects because of the immense external debt that has led to other serious economic debts. Policymakers in developing market 
economies should be more mindful about the value of successful external debt management if sustainable development is to be meaningful.

$>\quad$ Most significantly, the interests of stakeholders should be respected by stimulating domestic savings and local economic growth-oriented capital development, as this will encourage economic self-confidence and remove over-dependence on external debt. However, if external debt cannot be avoided, the goal (high priority projects) must be clearly established, and the debt must be effectively controlled to speed up economic growth (Ajao and Ogiemudia 2013). Furthermore, savings from external debt servicing should be ploughed into poverty alleviation initiatives, improving agriculture, and other sectors of the economy.

These postulations are fully consistent with the national guidelines of many countries and the guidelines of international organizations.

\section{Discussion}

Debt is indeed a very significant fiscal concept for the payment and receipt of individual, business and government financial transactions. It has emerged as a major player that can help to reduce inequality between and within nations because it supports citizens, entrepreneurs, companies, and governments to improve their circumstances. It is now accepted that debt is important, especially for emerging economies (IMF 2011). Many developing countries are now opting for external financing as a way to ensure sustainable growth along with domestic borrowing. The theory of the 'dual gap' posits that investment is a function of savings and that investment requiring domestic savings is not adequate to ensure economic growth, thus requiring complementary external sources of finance (Ajao and Ogiemudia 2013). Therefore, the theory specifies that the growth mechanism of a nation is heavily affected not only by internal borrowing but also by access to external borrowing.

Public debt covering internal and external borrowing has become a major engine of global development in the age of hyper globalization. Yet it has failed to produce a strong surge in productive investment and failed to fuel sustainable development, according to the 2019 UNCTAD report. Currently, public debt has become a serious problem in low-income countries, and its size now raises many doubts about further sustainable development. Around 40 percent of low-income countries may choose to default on their domestic and/or foreign debt or be forced to default (Harris and Lane 2018). In addition, contract renegotiations tend to cause output losses for a certain interval after default. As recognized in the SDGs and the Addis Ababa Action Agenda (AAAA), debt owed to rich countries is still an important vehicle for financing sustainable development goals in developing countries. Existing commitments in this regard should be met and exceeded. These scenarios suggest that in order to prevent crises that compromise attaining sustainability, governments must control the flow of income and expenditure, as well as the essence of the financial contracts they enter into, given that debt is a key element of any economic development strategy. The key financial commitments of a national government will simply not be possible to fulfill unless there is a serious commitment made to a more equitable redistribution of debt.

The notion of fair debt management relates directly to the equitable redistribution policy. The long-term debt market is weakened by the lack of equitability (Calvo 1997). A dramatic reduction in the debt / GDP ratio is necessary to reduce the government's temptation to repudiate 
the debt which could be attained if public debt is redistributed equally. In that viewpoint, public debt is designed as an amalgamation of expenditures where spending remains the same in each cycle, as this structure protects the budget from sudden changes (Barro 2003). Another viewpoint is that countries should employ their conventional taxation systems in such a way so that inflation does not erupt and simply worsens their debt burden (Lucas and Stokey 1983).

The relationship between private agents and the government often interferes in the choice of a public debt management plan. This interference is associated with the fair management of public debt containing optimal maturity. Although this approach was not enough to avoid the damaging effects of the 2008 global financial crisis (GFC) on European countries, Anderson et al. (2010) pointed out - based of a sample of 24 emerging economies - that the fair management of public debt (in particular an increase in the maturity of public debt) mitigated to some extent the GFC on these countries. As a whole policies able to neutralize foreign or domestic shocks that would endanger the fiscal balance are desirable (Kopits 2000). The bottom line is that to implement the SDGs there are only twelve years left. A vital window of opportunity is being opened by the gradual recovery of the global economy in the face of the COVID-19 pandemic, but it should ensure that the financing agenda is not derailed by the rising public debt.

\section{Conclusion}

Registration of higher resource requirements compared to potential capital generates calls for debts, especially in the less developed countries, for achieving sustainability by local or central governments or by public institutions. Their sum plus the equivalent interest indicates the level of public debt a country has. Countries are, for example, contrasted and graded according to the sustainability of public finance, beginning with public debt. Over the last decade, the global debt-to-GDP ratio has gradually risen (Tiftik et al. 2017; MGI 2015). This increase presents a high risk to global sustainable development because it is more likely that serious economic and financial crises will arise when debt levels reach certain thresholds (Reinhart and Rogoff 2009). Public debt, however, is not necessarily harmful; indeed, as long as it is managed well, it might even be advantageous up to a certain extent. The need to attain sustainable development requires, as a whole, implementation of different tactics with specific consequences. Through 'fair debts management' it possible for a country to escape such difficult circumstances, both politically and financially, and in terms of the casualties reported in the midst of a financial crisis and the impossibility of refinancing or repayment of loans. 'Fair debts management' balances each activity's social welfare gains with the costs produced by that activity's marginal contribution to default risk. It also plays a major role in ensuring 'debt sustainability'suggesting that countries with high public debt should take urgent immediate action to resolve their fiscal problems. Furthermore countries with moderate (or low) public debt should take the required precautions to preserve the level of their debt so that it avoids becoming a debtor nation - in effect a 'failed state'. Finally, renewed debt relief measures for highly distressed countries would have to be considered where debt levels are becoming clearly unsustainable due to exogenous shocks of capital flow, commodity prices or the state of the environment.

\section{Synonyms}

Debt; Public Debt; Debt sustainability; Fair Debt; Sustainable Development

\section{Cross-References}


$>\quad$ Global financial markets

$>\quad$ Financial soundness

$>\quad$ Regulation of global financial markets

\section{References}

Abdulkadri A (2014) Debt Sustainability and Sustainable Development in SIDS. In Debt and Development in Small Island Developing States (pp. 219-238). Palgrave Macmillan, New York.

Abdullahi MM, Abu N A B, Hassan SB (2016) Debt overhang versus crowding out effects: Understanding the impact of external debts on capital formation in theory. International Journal of Economics and Financial Issues, 6(1).

Adepoju, A. A.; Salau, A.S.; Obayelu, A.E. (2007). "The Effects of External Debt Management on Sustainable Economic Growth and Development: Lessons from Nigeria". Munich Personal RePEC Achieve (MPRA). Paper No. 2147

Ajao MG, Ogiemudia AO (2013) Foreign debt management and the development of Nigeria economy. Review of Economics \& Finance, 3, 99-109.

Anderson PRD, Silva AC, Velandia-rubiano A (2010) Public debt management in emerging market economies. Policy Research Working Paper, n. 5399.

Ari I, Koc M (2018) Sustainable financing for sustainable development: Understanding the interrelations between public investment and sovereign debt. Sustainability, 10(11), 3901.

Ayadi FS, Ayadi FO (2008) The impact of external debt on economic growth: A comparative study of Nigeria and South Africa. Journal of Sustainable Development in Africa, 10(3), 234-264.

Barro RJ (2003) Optimal management of indexed and nominal debt. Annals of Economics and Finance (4) (Beijing, Central University of Finance and Economics).

Blanchard O (2010) Ten Commandments for fiscal adjustment in advanced economies. The International Monetary Fund's Global Economy Forum, June 24.

Borensztein E (1990) Debt overhang, credit rationing and investment. Journal of Development Economics, 32(2), 315-335.

Bulow JI, Rogoff K (1988) Sovereign debt: Is to forgive to forget? (No. w2623). National Bureau of Economic Research.

Calderón C, Servén L (2004) The effects of infrastructure development on growth and income distribution. The World Bank.

Calvo G (1997) Capital Flows: Emerging Issues. Panel: 3 Are we in a Global Economic Crisis http://www.econ.yale.edu/alumni/reunion99/calvo3.htm.

Calvo G, Guidotti P (1990) Indexation and maturity of government bonds: an exploratory model. In: Dornbusch, R., Draghi, M. (Eds.), Public Debt Management: Theory and History. Cambridge University Press, Cambridge.

Cecchetti, S. G., Mohanty, M. S., \& Zampolli, F. (2011). The real effects of debt. Rev. Financ. Stud., 22, 25-27.

COMCEC Coordination Office (2017) Improving Public Debt Management in the OIC Member Countries. Ankara: COMCEC Coordination Office.

D’Mello, Ranjan, Mercedes M (2010) Long-term debt and overinvestment agency problem. Journal of Banking and Finance 34: 324-35. 
Default Research (2017) Infrastructure Default and Recovery Rates, 1983-2016; Moody's: New York, NY, USA.

Dernbach JC (2003) Achieving sustainable development: The Centrality and multiple facets of integrated decision-making. Indiana Journal of Global Legal Studies, 247-285.

Dincer I, Rosen MA (2005) Thermodynamic aspects of renewables and sustainable development. Renew Sust Energ Rev 9:169-189

Dominguez B (2005) Reputation in a model with a limited debt structure. Review of Economic Dynamics 8 (3), 600-622.

Dooley MP (2000) Debt management and crisis in developing countries. Journal of Development Economics, 63(1), 45-58.

Dottori D, Manna M (2016) Strategy and tactics in public debt management. Journal of Policy Modeling, 38(1), 1-25.

European Communities (1992) Treaty on European Union; European Communities: Brussels, Belgium.

Fischer S, Easterly W (1990) The economics of the government budget constraint. The World Bank Research Observer, 5(2), 127-142.

Gale D (1990) The efficient design of public debt. In: Dornbusch, R., Draghi, M._Eds.., Public Debt Management: Theory and History. Cambridge Univ. Press, Cambridge, England.

Georges P (2006) Borrowing short- or long-term: does the government really face a trade-off? Public Finance and Management 6 (2), 206-243.

Giavazzi F, Pagano M (1990) Confidence crises and public debt management. In: Dornbusch, R., Draghi, M. (Eds.), Public Debt Management: Theory and History. Cambridge University Press, Cambridge.

Harris E, Lane C (2018) Debt as an Obstacle to the Sustainable Development Goals. Available at: $\quad$ https://www.un.org/development/desa/en/news/financing/debt-as-an-obstacle-tosdgs.html (access on 27 April, 2018). Department of Economic and Social Affairs, United Nations, New York.

IMF. (1989). "World Economic Outlook." Washington DC: IMF.

IMF (2014). 'Revised Guidelines for Public Debt Management'. IMF Policy Paper 14/002. Washington, DC: IMF. https://doi.org/10.5089/9781498343602.007.

IMF-International Monetary Fund (2011) Strengthening Fiscal Credibility. Fiscal Monitor. International Monetary Fund, Washington. http://www.imf.org/external/pubs/ft/fm/ 2011/01/update/fmindex.pdf.

IMF (2018) "Macroeconomic developments and prospects in low-income developing countries", IMF Policy Paper, International Monetary Fund, Washington, DC, https://www.imf.org/en/Publications/Policy-

Papers/Issues/2018/03/22/pp021518macroeconomic-developments-and-prospects-inlides.

Jensen, Michael C (1986) Agency Costs of Free Cash Flow, Corporate Finance, and Takeovers. American Economic Review 76: 323-29.

Klein TM (1994) External Debt Management: An Introduction. The World Bank.

Kopits G (2000) How can fiscal policy help avert currency crises? IMF Working Paper, N. $00 / 185$.

Kregel J (2006) Rethinking debt sustainability in the context of the Millennium Development Goals. BNL Quarterly Review. 59(242):225-248.

Krugman P (1988) "Financing versus forgiving a debt overhang." Journal of Development Economics, Vol.29,pp. 253-68.

Lucas RE, Stokey NL (1983) Optimal fiscal and monetary policy in an economy without capital. Journal of Monetary Economics 12, 55-94. 
Marchesi S (2006) Buybacks of domestic debt in public debt management. European Journal of Finance 12 (5), 379-400.

MGI (2015) Debt and (Not. Much) Deleveraging; McKinsey Global Institute: New York, NY, USA, 2015; pp. 1-136.

Missale A, Giavazzi F, Benigno P (2002) How is debt managed? Learning from fiscal stabilization. The Scandinavian Journal of Economics 104 (3), 443-469.

Mitchener KJ, Weidenmier MD (2010) Supersanctions and sovereign debt repayment. Journal of International Money and Finance, 29(1), 19-36.

Myers, Stewart C (1977) Determinants of corporate borrowing. Journal of Financial Economics 5: 147-75. [CrossRef] Park, Bum-Jin. 2013. The Study on the Relation between Debt Characteristics and Audit Fee. Korea Business Education Research 28: 183-209.

Nicu M, Georgeta MM (2011) The need for public debt management in the context of sustainable development within the European Union. European Integration-New Challenges, 217.

Organization for Economic Co-operation and Development, OECD 92018) Global Outlook on Financing for Sustainable Development 2019: Time to Face the Challenge. Paris: OECD.

Oyejide TA, Soyede A, Kayode MO (1985) Nigeria and the IMF. Heinemann Educational book Nig. Ltd. Ibadan Pp. 9.

OPAŁKA B (2020) Conditions and Possibilities of Long-Term Public Debt Management. RAIS Journal for Social Sciences, 4(1), 110-119.

Pinto B (2018) The 2017 version of the IMF and World Bank's LIC Debt Sustainability Framework: "Significant overhaul" or obsolete? Available at https:// brianpintoeconomist.com/2018/06/17/the-2017- review-of-the-imf-and-world-banks-licdebt-sustainability- framework-significant-overhaul-or-obsolete/ (accessed 4 August 2019).

Reinhart CM, Rogoff KS (2009). This Time Is Different: Eight Centuries of Financial Folly; Princeton University Press: Princeton, NJ, USA.

Sachs JD (1989) “The Debt Overhang of Developing Countries." In Debt, Stabilization and Development. by Calvo, Guillermo A., Ronald Findlay, PenttiKouri, and Jorge Braga de Macedo, Oxford: Basil Blackwell.

Stoddart H (2011) A Pocket guide to sustainable development governance. Stakeholder Forum

Teică RA (2012) Analysis of the public debt sustainability in the Economic and Monetary Union. Procedia Economics and Finance, 3, 1081-1087.

Tiftik E, Mahmood K, Gibbs S, Tran H (2017) Global Debt Monitor; The Institute of International Finance: Washington, DC, USA.

UNCTAD (2019) Till debt do us part. Available at: https://unctad.org/news/til-debt-do-us-part (access on 26th September 2019).

United Nations (1992) Agenda 21; UN: Rio de Janerio, Brazil.

United Nations (2012) The Future We Want (Resolution Adopted by the General Assembly on 27 July 2012); UN: Geneva, Switzerland.

United Nations General Assembly (1987) Report of the world commission on environment and development: our common future. United Nations General Assembly, Development and International Co-operation: Environment, Oslo.

Weber B, Staub-Bisang M, Alfen HW (2016) Infrastructure as an asset class: investment strategy, sustainability, project finance and PPP. John wiley \& sons.

Wijeweera A, Dollery B, Pathberiya P (2005) Economic growth and external debt servicing: a cointegration analysis of Sri Lanka, 1952 to 2002. University of New England working paper series in economics, 8 .

Wolswijk G, de Haan J (2006) Government debt management in Europe: recent changes in debt managers' strategies. Public Finance and Management 6 (2), 244-277. 
World Commission on Environment and Development's, (the Brundtland Commission) report Our Common Future (Oxford: Oxford University Press, 1987). 